\title{
選択的近位迷切および全迷切術の胃運動におよぼす影響
}

\author{
岩手医科大学 第一外科教室 \\ (主任： 瀬田孝一教授) \\ 加 藤 貞 之
}

\section{EFFECTS OF SELECTIVE PROXIMAL AND TRUNCAL VAGOTOMY ON CANINE GASTRIC MOTILITY}

\author{
Sadayuki Kato \\ Depertment of Surgery, Iwate Medical University School of Medicine, Morioka.
}

(Director: Prof. K. Seta)

With the use of electromyography and intraluminal pressure recording of the pylorus, the effect of selective proximal and truncal vagotomy on the gastric motility was investigated in 10 dogs.

The results are summarized as follows:

1. Control dogs showed regular discharge intervals with elevation of intrapyloric pressure coinciding with the action potentials. There was seen no occurrence of antiperistalsis.

2. Selective proximal vagotomy resulted in the prolongation of discharge intervals along with slight decrease in the incidence of action potentials. The rate of antiperistalsis was $4.4 \%$. Besides, the rate of pyloric contraction also showed a a tendency of slight decrease.

3. Truncal vagotomy lead to the prolongation of discharge intervals and decrease in the incidence of action potentials, though these changes were milder than those after selective proximal vagotomy. The incidence of antiperistalsis was $6.8 \%$ which was higher than the one after selective proximal vagotomy. Elevation of intrapyloric pressure did not necessarily took place coinciding with the action potentials. Intrapyloric pressure as well as the incidence of pyloric contraction showed a marked decrease when compared with those of the control and selective proximal vagotomy dogs.

Out of these results, it is concluded that the selective proximal vagotomy is superior to the truncal vagotomy when viewed from the preservation of the gastric motility.

は じ め に

Dragstedt \& Owens (1943) により 消化性潰瘍 に対する外科治療として, 迷走神経切断術が報告 されて以来, 実験的, 臨床的に数多くの研究がな され，近年，本術式が普及の気運にある．現在， 潰瘍術式には大別して 2 つ方法があり，1つは
広節囲切除, も5 1 つは, 胃の切除範囲を可及的 に少くして迷走神経切断術を併施するか, 迷走神 経切断術のみを行ら方法である。いずれの方法で も大方は満足すべき結果が得られているが，ある 程度は, 本来胃の有している運動機能を犠牲とし 
ている. 迷走神経切断術においては, 全迷走神経 切断による消化管の運動機能の抑制を防ぐ術式と して，Griffith \& Harkins (1957) が選択的近位迷 走神経切断術を提唱し, さらに, Holle (1967) に より幽門洞の運動機能を温存する選択的近位迷走 神経切断術にドナージを併用した術式が提唱され
る様になった。また，迷走神経切断術の減酸効果 に対する研究報告は従来より数多く行なわれて来 たが，近年，胃運動の検討が注目されるようにな ってきた，そこで，著者も，これら術式の胃運動 に拉よぼす影響を, 胃筋電図, 幽門輪圧の面より 比較検討したので報告する.

\section{実験材料ならびに方法}

\section{I. 実 験 動 物}

体重 $10 \mathrm{~kg}$ 前後の雑種成犬, 10 頭を用いて実験 を行なった。後述する如く, 同一犬に対し, 単開 腹, 選択的近位迷走神経切断術, 全迷走神経切断 術の 3 種類の手術を施行した。

\section{II. 麻酔方法}

ネンブタール $25 \mathrm{mg} / \mathrm{kg}$ の静脈麻酔下に, 手術 施行中はレスピレーターを使用し, 胃筋電図, 内 圧測定はレスピレーターなしで行った。

\section{III. 迷走神経切断術式および測定までの期間}

\section{A. 対 照}

前述のごとく麻酔を行ない, 背臥位とし, 上正 中切開にて開腹を行ない, 後述する胃笳電図用電 極を図 1 のごとく幽門洞に 2 力所装着した。同時 に経口的に幽門輪に内压測定用バルーンを挿入し て測定を行ない, 測定直後に後述の選択的近位迷 走神経切断術 (以下, 選択的近位迷切と略す) を 施行した。

\section{B. 選択的近位迷走神経切断術}

胃を下方に率引し，小彎側胃角部で小網中に指 を挿入し，小網中を下降する迷走神経前枝を索状 物として触知し，これに，支持系をか子，Latarjet's fiber および，前幽門洞枝を確認した。前幽門洞 枝の第 1 枝のみを結禁切断し，他の前幽門洞枝は 温存した。ささら，支持系にて迷走神経前枝を率 引しつつ, 胃角部ょり食道噴門部まで，小彎側に 沿って胃に分枝する迷走神経を伴走する血管と共 に結禁切離した。後枝に関しても，前枝と同様の 操作を行った。迷走神経前, 後枝の本幹, 腹腔 枝，肝枝は確認のらえこれらを温存した。さら に，食道下端にて環状に外膜を剥離し，縦走する 率状物を総て結禁切離し, 選択的近位迷走神経切 断術を施行のらえ閉腹した。術後 4 週間以上経過 後に，ネンブタール静脈麻醉下に再開腹を行い, 対照群と同様に，筋電図用電極および幽門輪内圧 用バルーンを挿入して測定を行った。測定直後に

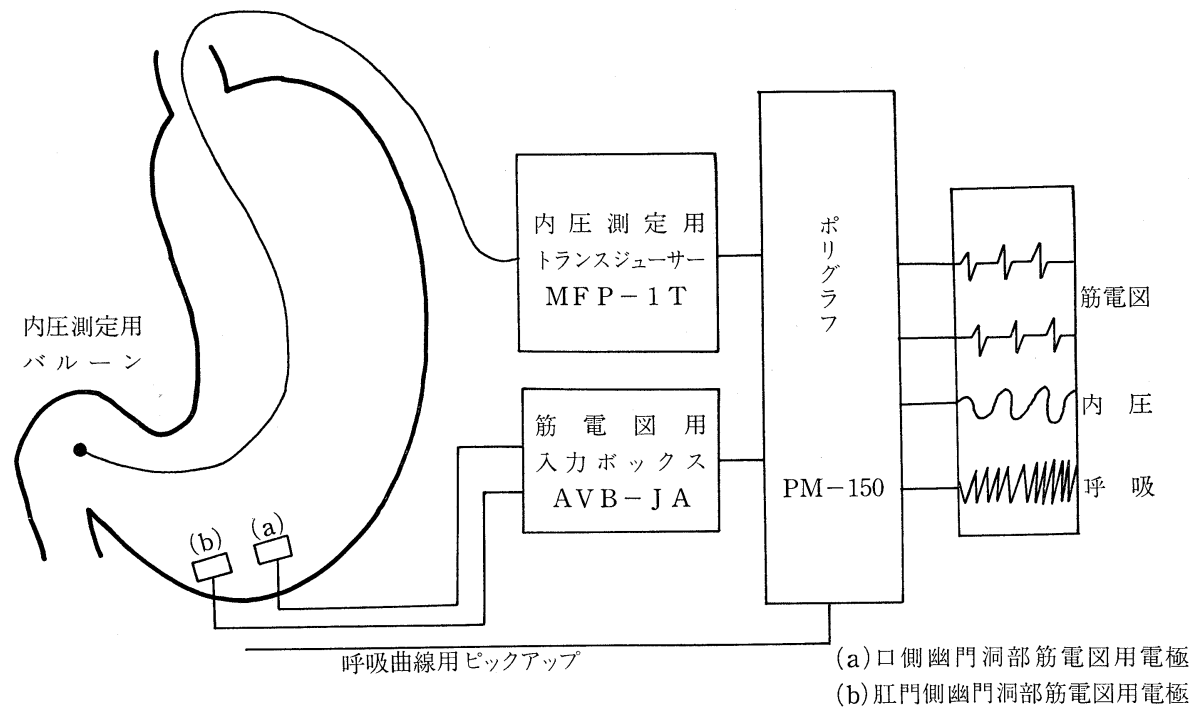

図 1. 筇電図, 内圧, 呼吸曲線記録法

（a）口側幽門洞部筋電図用電極 （b）肛門側幽門洞部筋電図用電極 
下記の全迷走神経切断術（以下，全迷切之略す） を施行した。

\section{C. 全迷走神経切断術}

前回の手術にて癒着した胃および肝臓を剝離 し, 迷走神経前枝・後枝を前回と同様にして確認 し, 前・後の幽門洞枝を結禁切断した。ついで, 食道下端に指を插入して食道全周を遊離のらえテ ープをかけ，これを下方に率引しながら腹腔枝， 肝枝の分枝点の上で迷走神経前枝・後枝本幹を切 離し, 食道裂口を閉鎖し, 閉腹した。全迷切術施 行後 4 週間以上経過してから, 再びネンブタール 静脈麻酔下に開腹し, 胃筋電図および，幽門輪内 圧の測定を行った。

\section{IV. 実験犬の管理方法}

手術前夜は絶食とし, 術後当日は, 生理的食塩 水, または $5 \%$ ブドウ糖 $500 \mathrm{~m} l$ を点滴静注する か, 皮下注射を行った。術後は原則として $500 \mathrm{mll}$ 日の皮下注射を 2 日間行った. 抗生物質は, 閉腹 前にセファロチンナトリウム，または合成ペニシ リン $0.5 \mathrm{~g}$ を腹腔内散布し, 術後は 1 日 $1 \mathrm{~g}$ 宛 4 日間筋注した。術後 2 日目より牛乳などの流動 食, 3〜5 日目より固型飼料を与た。実験犬は 1 頭 ずつドッグケージでかい, 術後 4 週間以上経過し て手術の影響がなくなってから術後の測定を施行 した。

\section{V、 筇電図の観察}

\section{A. 筋電図用の電極}

白金線を合成樹脂板に埋め込み, ビニールで絶 縁した銅線に接続した。合成樹脂板より露出した 白金電極を $5 \mathrm{~mm}$ の長さとし, 極間距離 $5 \mathrm{~mm}$ の 双極針電極を自作し，使用した。

\section{B. 電極の位置および固定方法}

上正中切開で開腹し, 胃の大彎側および幽門洞 部前壁に，2 個の電極を電極間距離を $1 \mathrm{~cm}$ とし て血管をさけて漿膜中に刺入し, ナイロン糸 2 針

\section{実験}

\section{I. 筋 電 図}

\section{A. 放電間隔 (表 1)}

対照 放電間隔は, 個々のイヌについて最低50 個以上の棘波頂点間の距離を測定した. 10 頭の総 放電数 778 個の最大放電間隔は, 15.2 秒, 最小放 電間隔は 11.2 秒で, 平均放電間隔は 13.3 秒であ
で固定した。

\section{C. 記録計の種類}

筋電図用電極は, 日本光電製の多用途観視記録 装置（RM-150 型）に接続した。記録はヘペーパ ースピード $1.25 \mathrm{~mm} / \mathrm{sec}$, 圧のキャリブレーショ ソは $10 \mathrm{mmHg}$ を $1 \mathrm{~cm}$ の条件下に，インク書き レコーダーで行った．筋電図用電極と多用途観視 記録装置間には, 日本光電製筋電図用入力ボック ス（AVBJA）を接続した。

\section{VI. 幽門輪内圧の観察}

A. 内圧測定用バルーン

長さ $60 \mathrm{~cm}$, 直径 $2 \mathrm{~mm}$ のシリコンチューブの 先端に容量 $1 \mathrm{ml}$ のコンドーム製バルーンを装着 したものを自作した。

\section{B. 内圧用バルーン挿入部位}

経口的に内圧測定用バルーンを插入し，噴門部 より用手的にバルーンを誘導して幽門輪にバルー ソの先端中央が密着するように装着し，かつ， ハ ルーンが十二指腸に移動しないように，シリコン チューブをイヌのロに固定した。

\section{C. 記録計の種類}

内压測定用バルーンに空気 $1 \mathrm{~m} l$ を注入し，日 本光電製内圧測定用トランスジューサー (MFP1T）に接続し，さらに日本光電製多用途観視記録 装置(RM-150) に接続した。記録は，圧のキャリ ブレーションで $1 \mathrm{~cm}$ が $10 \mathrm{mmHg}$ となるよらな 条件下に、インク書きレコーダーで行った.

\section{VII. 開腹から測定までの時間的関係}

開腹し, 筋電図用電極, 幽門輪内圧用バルーン を装着した直後は，胃の放電，および，蠕動運動 は，種々の因子により一定とならない，従って筋 電図の波形，また，幽門輪内圧の大きさも不安定 となるので, これらの胃運動が安定するまで約 60 分間以上経過してから測定を開始したが，この間 は無処置とした。

\section{成 績}

った１0頭個々の放電間隔をみるとイイヌにより 多少の相違がみられるが，大きな差位は認められ ず，また，No. 2, No.5のイヌのように同一犬の 測定で, 放電間隔が多少延長, 短縮を示すものも あったが, 図 2 のごとく比較的一定の間隔を有す る放電がみられた。 
表 1. 選近迷切後, 全迷切後の放電間隔の変化

\begin{tabular}{|c|c|c|c|}
\hline Dog No. & 対 $_{(\text {秒) }}$ & $\frac{\text { 選近迷切後 }}{\text { (秒) }}$ & $\frac{\text { 全迷切後 }}{\text { (秒) }}$ \\
\hline 1 & 14.4 & $12.5-25.6$ & $14.4-17.6$ \\
\hline 2 & $12.8-14.4$ & $20.0-30.0$ & $15.2-16.0$ \\
\hline 3 & 12.0 & $14.4-28.0$ & $12.8-40.0$ \\
\hline 4 & 11.2 & 12.8 & $16.0-29.6$ \\
\hline 5 & $12.9-15.2$ & $12.6-13.6$ & $12.0-32.0$ \\
\hline 6 & 13.6 & 11.2 & 13.6 \\
\hline 7 & 13.8 & $8.0-44.0$ & $3.8-21.2$ \\
\hline 8 & 13.6 & 13.6 & 13.0 \\
\hline 9 & 12.0 & $14.4-28.0$ & $8.8-32.0$ \\
\hline 10 & 12.8 & $13.0-16.0$ & 16.0 \\
\hline 10頭中最大 & 15.2 & 44.0 & 40.0 \\
\hline 10頭中最小 & 11.2 & 8.0 & 3.8 \\
\hline 10頭平均 & 13.3 & 17.5 & 16.8 \\
\hline
\end{tabular}

選迷的近位迷走神経切断術後 対照と同様に測定 を行ない, 10 頭の総放電数 812 個を測定した中 で，最大放電間隔は 44 秒と著明に 延長したもの があり, また, 最小放電間隔は 8 秒で, 平均放電
間隔は 17.5 秒であった。放電間隔は著明に延長 するもの, また, 短縮するものがみられ, 同一犬 の測定でも図 3 のように放電間隔は一定となら ず,なかにはやや延長傾向を示すのが認められ た。

全迷走神経切断術後 前 2 者と同様に測定を行っ た. 10 頭の総放電数 822 個を測定した最大放電間 隔は 40 秒, 最小放電間隔は 3.8 秒で, 平均放電 間隔は 16.8 秒であった．対照と比較すると，選 択的近位迷切後と同様に，放電間隔は著明に延長 するものと短縮するものがあった。また，図４の ように各放電間隔も一定せず，むしろ延長傾向を 示しているが，平均でみると選択的近位迷切後よ りは多少短縮しているのが認められた。

\section{B. 放電頻度 (表 2)}

対照 1 分間の平均放電頻度は, 平均放電間隔 が 13.3 秒であるので 4.5 回であった。また，個 々のイヌについてみると放電頻度の最も多いもの は放電間隔が 11.2 秒で 5.3 回／分であり，放電

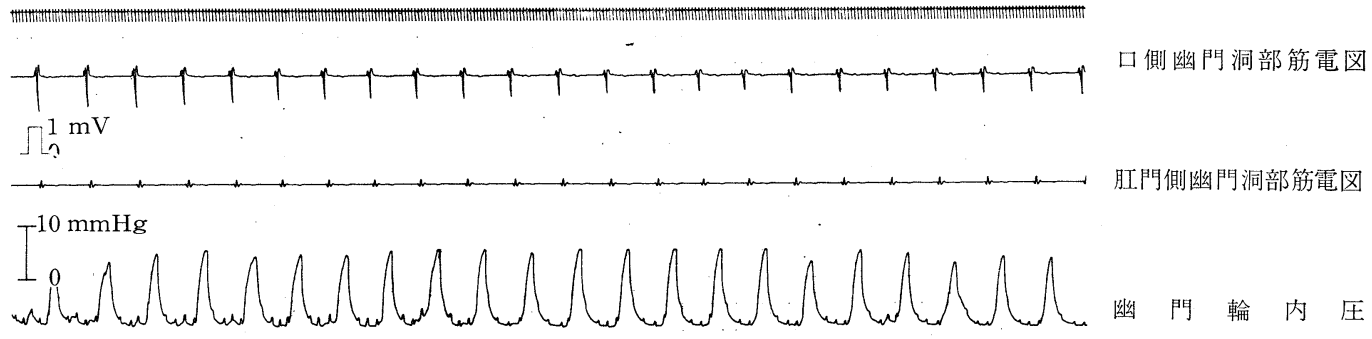

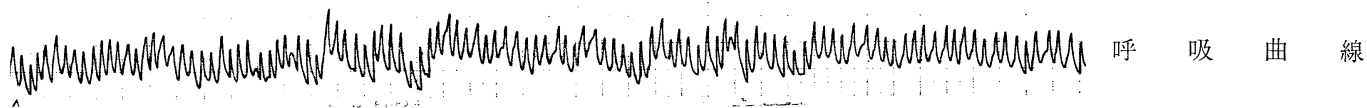

図 2. 対照大の筋電図および幽門輪内圧

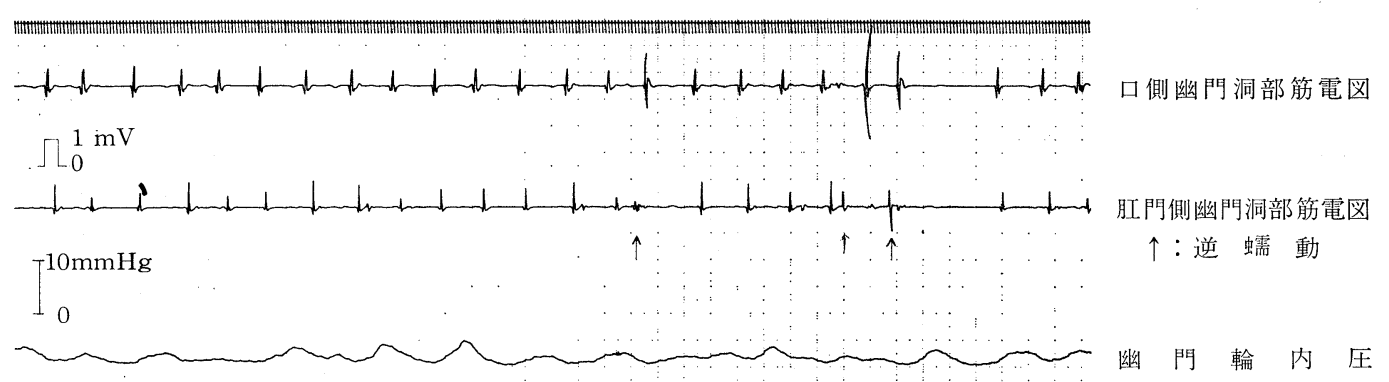

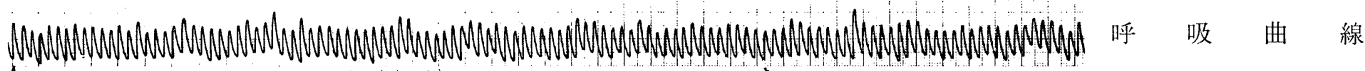

図 3. 選択的近位迷切後の筋電図および幽門輪内圧 


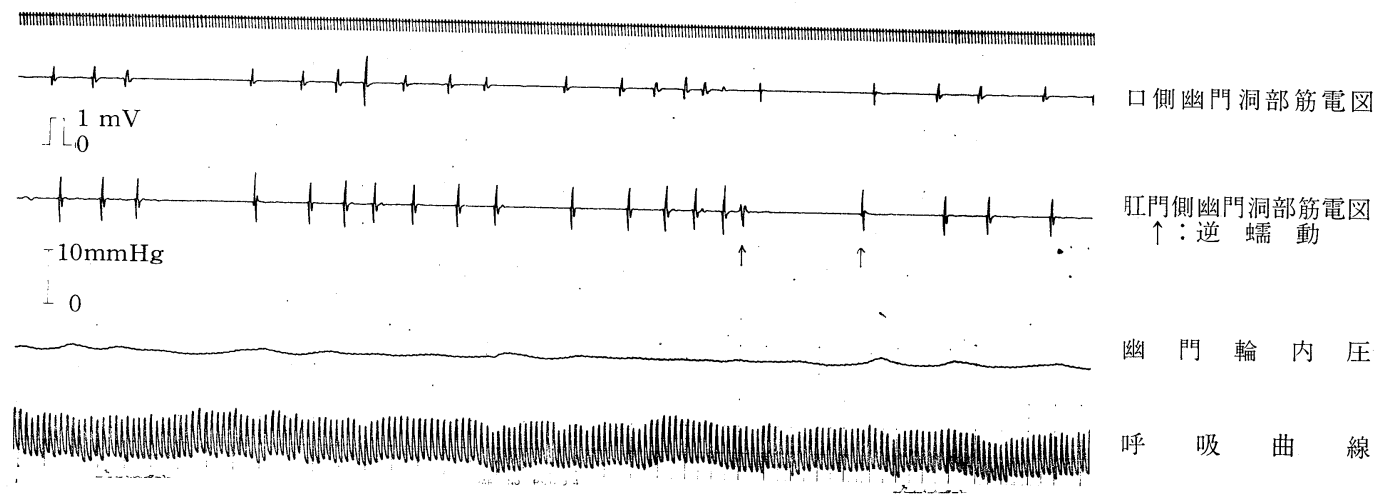

図 4. 全迷切後の筋電図および幽門輪内圧

表 2. 選近迷切, 全迷切後の放電頻度

\begin{tabular}{c|c|c|c}
\hline & $\begin{array}{c}\text { 対 } \\
\text { (回/分) }\end{array}$ & $\begin{array}{c}\text { 撰近迷切後 } \\
\text { (回/分) }\end{array}$ & $\begin{array}{c}\text { 全迷切後 } \\
\text { (回/分) }\end{array}$ \\
\hline 1 & 4.1 & $2.3-4.8$ & $3.4-4.1$ \\
2 & $4.1-4.6$ & $2-3$ & $3.7-3.9$ \\
3 & 5 & $2.1-4.1$ & $1.5-4.6$ \\
4 & 5.3 & 4.6 & $2-3.7$ \\
5 & $3.4-3.9$ & $2.7-4.4$ & $1.8-5$ \\
6 & 4.4 & 5.3 & 4.4 \\
7 & 4.3 & $1.3-7.5$ & $2.8-15.8$ \\
8 & 4.4 & 4.4 & 5 \\
9 & 5 & $2.1-4.1$ & $1.8-6.8$ \\
10 & 4.6 & $3.8-4.6$ & 3.7 \\
\hline 10 頭平均 & 4.5 & 3.4 & 3.6 \\
\hline
\end{tabular}

頻度の最も少ないものは放電間隔が 15.2 秒で 3.4 回/分であった。

選迷的近位迷走神経切断術後 1 分間の平均放電 頻度は, 平均放電間隔が 17.5 秒であるので 3.4 回/分であった．個々のイヌについてみると，放 電頻度の最も多いものは放電間隔が 8.0 秒で 7.5 回／分であり，放電頻度の最も少ないものは放電 間隔が 44.0 秒で 1.3 回/分となり, 対照と比較 して著明に増加するもの, また, 減少するものが あったが，平均してみると放電頻度の減少がみら れた。

全迷走神経切断術後 1 分間の平均放電頻度は, 平均放電間隔が 16.8 秒であるので 3.6 回/分と なる。また, 個々のイヌでは最多放電頻度を示す

表 3. 逆蠕動 の 発生頻 度

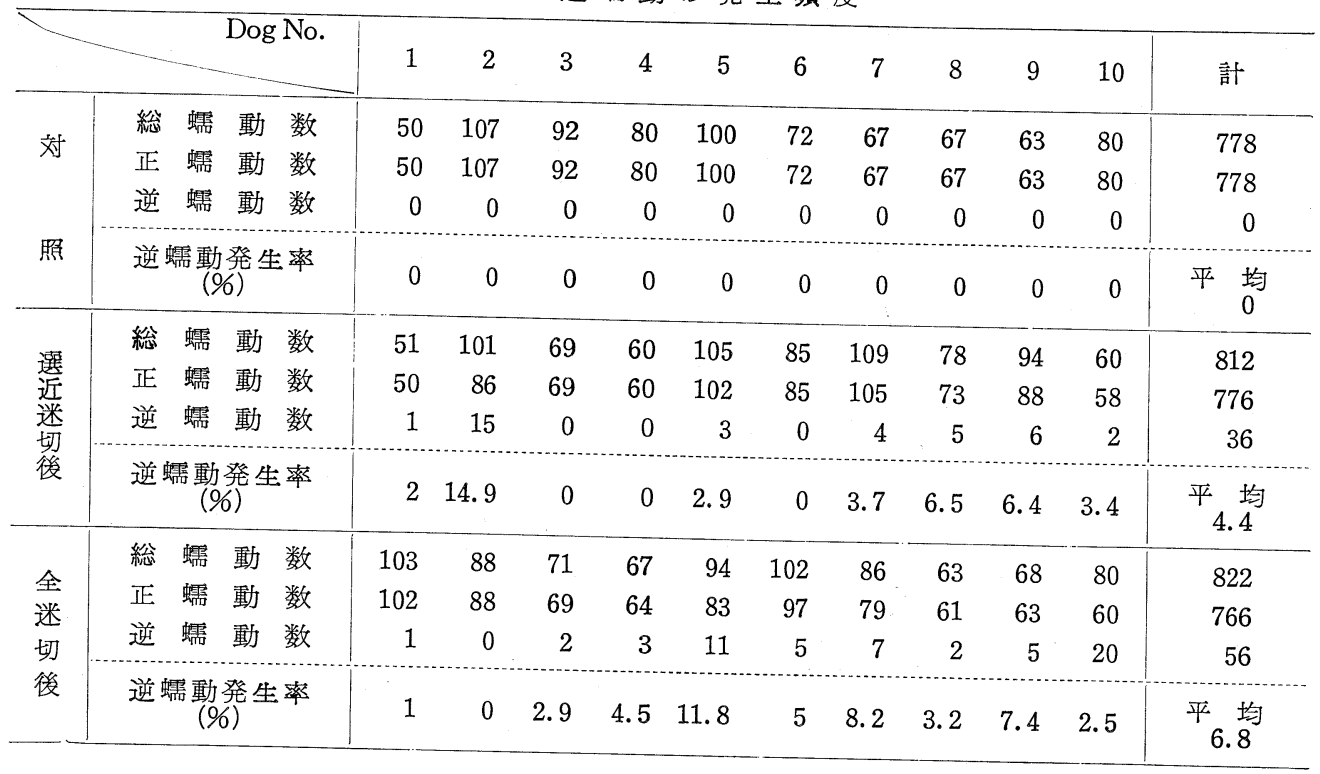


ものは放電間隔が 3.8 秒で 15.8 回/分であり, 最少放電頻度を示するのは放電間隔が 40.0 秒で 1.5 回/分であった。対照と比較すると前者と同 様に大きなバラッキがあり，また，平均でみると 放電頻度の減少が認められた。

\section{C. 逆蝡動の発生頻度（表 3)}

対照 10 頭の総蠕動数 718 個を検討したが, 図 2 のように総て正蠕動だけで, 逆蠕動は認めら れなかった。

選迷的近位迷走神経切断術後 10 頭のらち，図 3 のよらに逆蠕動の認められたのは 7 頭であり, 10 頭の逆蠕動の平均発生頻度は総蠕動数 812 個に対 して，逆蠕動数 36 個で $4.4 \%$ であった。 また， 個々のイヌについてみると, 逆蠕動の発生頻度の 最も多いものは, 総蠕動数 101 個に対し, 逆蠕動 数 15 個で $14.9 \%$ であり, 発生頻度の最も低いも のは総蠕動数 51 個に対し, 逆蠕動数 1 個で $2 \%$ であった。

全迷走神経切断術後 10 頭のうち図4のように逆 蠕動の認められたのは 9 頭あり, 10 頭の平均逆 蠕動発生頻度は総蠕動数 822 個に対し, 逆蠕動数 56 個で $6.8 \%$ であった。また，9頭のらちで，発 生頻度の最も多いものは総蠕動数 80 個に対し, 逆蠕動数 20 個で $25 \%$, 発生頻度の最も少いもの は総蠕動数 103 個に対し, 逆蠕動数 1 個で $1 \%$ で あった。逆蠕動の発生頻度は, 平均してみると選 択的近位迷切後と比較してやや増加の傾向がみら れた。
D. 振幅（表 4)

対照 10 頭の 778 個の䊂波を測定した平均電 位は $0.8 \mathrm{mV}$ であった.また, 最大電位は $2.2 \mathrm{mV}$, 最小電位は $0.2 \mathrm{mV}$ であったが, 同一犬について みるとほぼ一定の大きさの電位であった。

選迷的近位迷走神経切断術後 10 頭の 812 個の棘 波を測定した平均電位は， $0.7 \mathrm{mV}$ であった。 た，最大電位は $2.0 \mathrm{mV}$, 最小電位は $0.1 \mathrm{mV}$ であ った。なお，同一犬の測定で時折大きな棘波を認 めたが，内压の大きさに変化は起らなかった。

全迷走神経切断術後 10 頭の 822 個の棘波を測定 した平均電位は $0.8 \mathrm{mV}$ で, 最大電位は $4.2 \mathrm{mV}$, 最小電位は $0.1 \mathrm{mV}$ であった。選択的近位迷切後 と同様に，時折大きな棘波が出現することがあっ たが，内圧には大きな変化はみられなかった。ま た，平均電位をみると，対照と迷切後には大した 変化はなかったが, 迷切後には時折単発的に大き な棘波が出現するのがみられたが，内圧には何ら 变化を認めなかった。

\section{E. 伝播速度}

伝播速度は測定不可能のものが 6 頭あり, 測定 し得たものは何れも 1.6 秒または 2.4 秒で, 同一 犬で術前・術後とも測定し得たものでは変化を認 めなかった。

\section{II. 幽門輪内圧および幽門運動の変化}

A. 幽門輪内圧 (表 5)

対照 10 頭の平均幽門輪内圧は $12.2 \mathrm{mmHg}$ で あった。個々のイヌの幽門輪内圧をみると, 最大 $35 \mathrm{mmHg}$ から最小 $5.5 \mathrm{mmHg}$ と約 $30 \mathrm{mmHg}$ の

表 4. 選近迷切, 全迷切後の振幅

\begin{tabular}{|c|c|c|c|c|c|c|c|c|c|}
\hline \multirow[b]{2}{*}{ Dog No. } & \multirow{2}{*}{$\frac{\text { 対 }}{\text { 最大 }}$} & \multicolumn{2}{|c|}{ 照 (mV) } & \multicolumn{3}{|c|}{ 選近迷切後 $(\mathrm{mV})$} & \multicolumn{3}{|c|}{ 全迷切後 $(\mathrm{mV})$} \\
\hline & & 最小 & 平均 & 最大 & 最小 & 平均 & 最大 & 最小 & 平均 \\
\hline 1 & 0.9 & 0.9 & 0.9 & 0.3 & 0.3 & 0.3 & 1.4 & 1.4 & 1.4 \\
\hline 2 & 1.9 & 0.2 & 0.9 & 1.0 & 0.2 & 0.3 & 1.0 & 0.6 & 0.8 \\
\hline 3 & 0.4 & 0.2 & 0.3 & 0.5 & 0.3 & 0.4 & 0.4 & 0.1 & 0.2 \\
\hline 4 & 0.9 & 0.7 & 0.9 & 0.4 & 0.1 & 0.2 & 1.0 & 0.2 & 0.4 \\
\hline 5 & 1.5 & 1.0 & 1.4 & 1.3 & 1.3 & 1.3 & 4.2 & 0.8 & 1.1 \\
\hline 6 & 0.5 & 0.2 & 0.4 & 2.0 & 2.0 & 2.0 & 1.0 & 0.5 & 0.8 \\
\hline 7 & 1.2 & 0.9 & 0.9 & 0.9 & 0.1 & 0.5 & 1.4 & 0.2 & 0.5 \\
\hline 8 & 0.6 & 0.3 & 0.5 & 1.6 & 0.2 & 0.5 & 0.7 & 0.3 & 0.6 \\
\hline 9 & 2.2 & 1.2 & 1.3 & 1.1 & 0.6 & 0.7 & 0.9 & 0.4 & 0.7 \\
\hline 10 & 0.8 & 0.4 & 0.6 & 0.3 & 0.2 & 0.3 & 2.9 & 0.6 & 1.0 \\
\hline 10頭平均 & 1.0 & 0.6 & 0.8 & 0.9 & 0.5 & 0.7 & 2.9 & 0.5 & 0.8 \\
\hline
\end{tabular}


表 5. 選近迷切, 全迷切後の幽門輪内圧

\begin{tabular}{|c|c|c|c|c|c|c|c|c|c|}
\hline \multirow[b]{2}{*}{ Dog No. } & \multicolumn{3}{|c|}{ 対 照 $(\mathrm{mmHg})$} & \multicolumn{3}{|c|}{ 選近迷切後 (mmHg) } & \multicolumn{3}{|c|}{ 全迷切後 $(\mathrm{mmHg})$} \\
\hline & 最大 & 最小 & 平均 & 最大 & 最小 & 平均 & 最大 & 最小 & 平均 \\
\hline 1 & 15 & 6 & 10 & 9 & 2 & 4.5 & 5 & 0 & 2.1 \\
\hline 2 & 12.5 & 5 & 7.5 & 10 & 2.5 & 5 & 2 & 1 & 1.5 \\
\hline 3 & 13 & 3 & 10.5 & 8 & 3 & 5 & 7 & 0 & 1.5 \\
\hline 4 & 35 & 16 & 30 & 20 & 7 & 13 & 5 & 0 & 1.3 \\
\hline 5 & 12.5 & 7 & 9.5 & 16 & 3 & 8 & 10.5 & 0 & 3 \\
\hline 6 & 9 & 6 & 8 & 15 & 2.5 & 6.9 & 4 & 0 & 1.4 \\
\hline 7 & 14 & 12 & 13.5 & 11 & 4 & 5.8 & 3.5 & 0 & 0.8 \\
\hline 8 & 15 & 5.5 & 8.5 & 8 & 4 & 5.5 & 3.5 & 0 & 1.2 \\
\hline 9 & 17.5 & 6 & 11 & 15 & 3.5 & 7.9 & 11 & 0 & 2.4 \\
\hline 10 & 15 & 11 & 13.5 & 12.5 & 2 & 8.5 & 6 & 0 & 2.5 \\
\hline 10頭平均 & 15.9 & 9.8 & 12.2 & 12.4 & 3.4 & 7.0 & 5.8 & 0.1 & 1.8 \\
\hline
\end{tabular}

大きな差異がイヌによってみられた。しかし，同 一犬の内圧では図 2 のよらに比較的一定の大きさ の幽門輪内圧の上界がみられた。

選迷的近位迷走神経切断術後 10 頭の平均幽門輪 内圧は $7.0 \mathrm{mmHg}$ であり, 最大 $20 \mathrm{mmHg}$, 最小 は $2 \mathrm{mmHg}$ であった。 対照と比較すると, 平均 幽門輪内圧は約 40\% 低下し, 同一犬の内圧測定 に敃いても, 図 3 のように内压の高低差が著明で あり，压上昇曲線が 不安定となるのが認められ た。

全迷走神経切断術後 10 頭の平均幽門輪内压は $1.8 \mathrm{mmHg}$ で, 最大 $11 \mathrm{mmHg}$, 最小は $1 \mathrm{mmHg}$ で あった. 幽門輪内圧は選択的近位迷切後と比較し
て 74\%の著明な低下がみられた。ささらに対照と の比較でも $85 \%$ の著明な低下がみられ，図40 ごとく内压は全般的に低くなり, 同一犬の測定で も内圧の変化は選択的近位迷切後と比較しても著 明な差異が認められた。

\section{B. 幽門輪収縮頻度 (表 6)}

対照 幽門輪収縮頻度は, 総放電数に対する幽 門輪収縮総数との割り合いより算定した. 対照で は 10 頭の放電総数 778 個に対し, 幽門輪収縮総 数 778 個で平均 $100 \%$ の収縮頻度であった。これ は図 2 のように放電直後に一致して幽門輪の収縮 が起こる事を示している.

選迷的近位迷走神経切断術後 10 頭の収縮頻度は,

表 6. 選近迷切, 全迷切後の幽門輪収縮頻度

\begin{tabular}{|c|c|c|c|c|c|c|c|c|c|c|c|c|}
\hline \multicolumn{2}{|c|}{ Dog No. } & 1 & 2 & 3 & 4 & 5 & 6 & 7 & 8 & 9 & 10 & 計 \\
\hline \multirow{2}{*}{ 対 } & 総 放 電 数 & 50 & 107 & 92 & 80 & 100 & 72 & 67 & 67 & 63 & 80 & 778 \\
\hline & 幽門輪収縮総数 & 50 & 107 & 92 & 80 & 100 & 72 & 67 & 67 & 63 & 80 & 778 \\
\hline 照 & $\begin{array}{c}\text { 収 縮 頻 度 } \\
(\%)\end{array}$ & 100 & 100 & 100 & 100 & 100 & 100 & 100 & 100 & 100 & 100 & $\begin{array}{c}\text { 平 均 } \\
100\end{array}$ \\
\hline \multirow{3}{*}{$\begin{array}{l}\text { 選 } \\
\text { 近 } \\
\text { 迷 } \\
\text { 後 }\end{array}$} & 総 放 電 数 & 51 & 101 & 69 & 60 & 105 & 85 & 109 & 78 & 94 & 60 & 812 \\
\hline & 幽門輪収縮総数 & 50 & 88 & 64 & 54 & 99 & 73 & 99 & 71 & 80 & 58 & 736 \\
\hline & $\begin{array}{c}\text { 收 縮 頻 度 } \\
(\%)\end{array}$ & 98 & 87.1 & 93.4 & 90 & 94.2 & 85.8 & 90.8 & 91 & 85.1 & 96.6 & $\begin{array}{c}\text { 平 均 } \\
90.9\end{array}$ \\
\hline \multirow{3}{*}{$\begin{array}{l}\text { 全 } \\
\text { 迷 } \\
\text { 切 } \\
\text { 後 }\end{array}$} & 総 放 電 数 & 103 & 88 & 71 & 67 & 94 & 102 & 86 & 63 & 68 & 80 & 822 \\
\hline & 幽門輪収縮総数 & 53 & 78 & 49 & 33 & 53 & 62 & 55 & 32 & 29 & 39 & 483 \\
\hline & $\begin{array}{c}\text { 収 縮 } \text { 頻 度 } \\
\text { (\%) }\end{array}$ & 51.4 & 88.6 & 69 & 49.2 & 56.3 & 60.7 & 63.9 & 50.7 & 42.6 & 48.7 & $\begin{array}{l}\text { 平 均 } \\
58.6\end{array}$ \\
\hline
\end{tabular}


表 7. 選近迷切，全迷切後の幽門收縮数

\begin{tabular}{|c|c|c|c|c|c|c|}
\hline \multirow[b]{2}{*}{ Dog No. } & 対 & 照 & \multicolumn{2}{|c|}{ 選近迷切後 } & \multicolumn{2}{|c|}{ 全迷切後 } \\
\hline & $\begin{array}{l}\text { 幽門収縮数 } \\
\text { (回/320秒) }\end{array}$ & $\begin{array}{l}1 \text { 分間の平均 } \\
\text { 幽門収縮数 }\end{array}$ & $\begin{array}{l}\text { 幽門収縮数 } \\
\text { (回/320秒) }\end{array}$ & $\begin{array}{l}1 \text { 分間の平均 } \\
\text { 幽門収縮数 }\end{array}$ & $\begin{array}{l}\text { 幽門収縮数 } \\
\text { (回/320秒) }\end{array}$ & $\begin{array}{l}1 \text { 分間の平均 } \\
\text { 幽門収縮数 }\end{array}$ \\
\hline 1 & 21 & 3.9 & 15 & 2.8 & 12 & 2.3 \\
\hline 2 & 23 & 4.3 & 15 & 2.8 & 10 & 1.9 \\
\hline 3 & 26 & 4.9 & 17 & 3.1 & 7 & 1.3 \\
\hline 4 & 26 & 4.9 & 25 & 4.6 & 11 & 2.0 \\
\hline 5 & 24 & 4.5 & 23 & 4.3 & 10 & 1.9 \\
\hline 6 & 26 & 4.9 & 27 & 5.0 & 18 & 3.4 \\
\hline 7 & 22 & 4.1 & 14 & 2.6 & 12 & 2.3 \\
\hline 8 & 23 & 4.3 & 23 & 4.3 & 20 & 3.8 \\
\hline 9 & 26 & 4.9 & 21 & 3.9 & 7 & 1.3 \\
\hline 10 & 24 & 4.5 & 21 & 3.9 & 15 & 2.8 \\
\hline 10頭平均 & 24 & 4.5 & 20 & 3.7 & 12 & 2.3 \\
\hline
\end{tabular}

総放電数 812 個に対し収縮総数が 736 個で平均 90.9\%であった。個々のイヌについて収縮頻度 をみると，最多頻度を示したのは総放電数 51 個 に対し収縮総数 50 個, $98 \%$ のイヌでありま た, 最少頻度は総放電数 94 個に対し収縮総数 80 個，85.1\%のイヌであった。これは図 3 のごとく 放電に汇ぼ一致して幽門輪の収縮が起こることを 示している。

全迷走神経切断術後 10 頭の幽門輪収縮頻度は総 蠕動数 822 個に対し総蠕動数に対し収縮総数 483 個で平均 $58.6 \%$ であった. 個々のイヌについて みると, 最多収縮頻度を示したものは総蠕動数 88 個に対し収縮総数 78 個, $88.6 \%$ のイスであっ た。また，最少収縮頻度のものは総蠕動数 68 個 に対し収縮総数 29 個で $42.6 \%$ であった．以上よ り全迷切後では放電直後に注ぼ一致して幽門輪の 収縮の起こるものもあったが，図4のように多く は放電に一致して幽門輪の収縮が起こるとは限ら ず，放電が起こっても幽門輪の収縮が休止するこ とも多く認められるようになった。

\section{G. 幽門収縮数（表 7)}

対照 幽門収縮数の測定は, 各犬とも 320 秒中 の幽門収縮数を測定することに統一した．対照で は, 全 10 頭の平均幽門収縮数は 320 秒中に平均 収縮数が 24 回あり, 1 分間に換算すると 4.5 回で

\section{考}

消化性潰瘍に対する術式の 1 つとして，近年迷 走神経切断術（以下，迷切と略す）が本邦でも普
あった。また，個々のイヌについてみると，幽門 収縮数が最も多かったのは 320 秒中 26 回のもの で, 1 分間の最多幽門収縮数は 4.9 回であった. 幽門収縮数が最も少なかったのは 320 秒中 21 回 で, 1 分間の最少幽門収縮数は 3.9 回であった.

選迷的近位迷走神経切断術後 10 頭の平均幽門収 縮数は 320 秒中に平均収縮数が 20 回あり, 1 分間 の值に換算すると 3.7 回であった。すた，個々の イメについてみると, 幽門収縮数が最も多いのは 320 秒中 27 回で 1 分間の最多幽門収縮数は 5 回 であった．幽門収縮数が最も少ないのは 320 秒中 14 回で， 1 分間の最少幽門収縮数は 2.6 回であっ た。対照と比較して，個々のイヌで 1 分間の最 多, 最少幽門収縮数では差異を認めないが，平均 収縮数では多少減少しているのがみられる。

全迷走神経切断術後 10 頭の平均幽門収縮数は 320 秒中に平均収縮数が 12 回で， 1 分間に換算す ると 2.3 回であった。また，個々のイヌについて みると，幽門収縮数が最も多いのは 320 秒中 20 回で, 1 分間の最多幽門収縮数は 3.8 回であり, 幽門収縮数が最も少ないのは 320 秒中 7 回で, 1 分間の最少幽門収縮数は 1.3 回であった。選択的 近位迷切後と比較すると, 幽門収縮数は減少し, さらに，対照と比較しても著明に減少しているの がみられた。

\section{案}

及しつつある。 Dragstedt \& Owens (1943) は十 二指腸潰瘍に対する迷切を発表した。しかし，全 
迷走神経切断術（以下，全迷切と略す）のみでは 胃内容停帯にもとづく幽門洞の拡張刺激により逆 に胃分泌充進を招くことが解り, 胃腸吻合が付加 されるようになった，その後 Weinberg (1963) は ドレナージの方法として幽門形成術を発表してい る. 一方, 全迷切では肝枝を損傷するために胆道 系や膵の運動, 分泌障害を伴い, また, 腹腔枝の 損傷によって腸管の機能障害を伴らことが問題と なってきた。そこで, このような問題の解決策と して, Griffith \& Harkins (1957) がイヌを用いて 肝枝, 腹腔枝を温存し, また幽門洞, 幽門輪への 迷走神経を温存し, 胃体部, 胃底部の酸, ペプシ ン分泌領域のみの迷切を行ら選択的近位迷切を提 唱した. ついで, Holle (1967) は全迷切, 選迷切 による胃運動障害の改善を目的として, 選択的近 位迷切にドレナージを併用した選択的近位迷切を 提唱し，榊原（1973）も本邦で施行している。ま た,これら術式の減酸効果に関する研究は従来よ り数多く行われて拈り, 胃運動に打よぼす影響に 関しても, 近年本邦に拈いて, 胃筋電図やひずみ 曲線などを用いて種々の角度から盛んに検討され つつあるが，未知の問題も少くないように思われ る、そこで, 著者もこれら術式の胃運動に及ぼす 変化を胃筋電図および内圧の点から実験的に比較 検討してみた。

実験方法に関して言及すると，筋電図，幽門輪 内圧の両者を長時間にわたり同時に記録する必要 から, 麻酔剤としては軽いネンブタール麻酔を用 いた，麻酔剤の影響に関して，大井ら（1963）は 各種麻酔下で胃活動電位を記録し, 局所麻酔下の ものと対比しているが，ラボナール，笑気では殆 んぞ影響を認めず，エーテル深麻酔では強い抑制 作用, 扣よび放電頻度, 振幅の減少を認めてい る。また, 菅原ら（1970）は迷走神経の介在が麻 酔と深い関連性があるため, 麻酔の種類, 用量, 麻酔深度を充分考虑する必要があるとしている。 そこで著者は, 比較的長時間作用の浅いネンブタ 一ル麻酔による開腹実験を行ない, 迷切後 4 週以 上おいてから胃筋電図, および幽門輪内圧の観察 を行ったが, 明らかに急性実験とは異なり, 一応 慢性実験に準ずるものと考えてよいように思う。

急性実験による消化管平滑筋筋電図, および収 縮曲線を用いた消化管機能研究報告は多数ある が, 田中ら（1975）の行っているような植込み電
極を使用した慢性実験による生理的状態に近い実 験観察は少ない。その主な理由としては, 耐久性 のある電極の製作が困難であること，長期にわた る安定した電極の植込み方法が難しいこと, 第 2 次, 第 3 次の手術操作が同一動物に抹いて困難で あること, 電極留置下の動物の管理が容易でない ことなどがあげられ, 中でも耐久性, 持久性のあ る電極の製作が問題である。桑島ら（1975）は銀 針双極電極を使用し，4 力月間の植込みでも良好 な結果を得たと報告している，著者は白金製電極 を自作し，急性実験では良好な結果をえたが，植 込みした場合には, やはり電極の感度減少を認め ざるをえず，電極は測定のたびに装着することと なった。

内圧測定用バルーンは, 大井ら（1966）はバル ーンが実験中幽門から脱落しないよう3 連バルー ンやつば付きバルーンを考案した. しかし，幽門 といら1つの輪を, ある長さの円柱で観察する不 合理さを考学てひずみ針も使用してみたが，バル ーン, ひずみ針のいずれによっても前庭部の放電 に一致した収縮曲線が描かれたと結論している。 著者も当初 2 連のバルーンを使用してみたが, 蠕 動によりバルーンが十二指腸に移動するため単式 バルーンを用いることとした。 バルーンに接続し たチューブをイヌのロに固定することにより，バ ルーンの移動, 脱落の防止に努めたが, 時には蠕 動によるズレを生じ，再固定を必要とした。

筋電図の知見を総括すると，まず，放電間隔は 対照では平均 13.3 秒と比較的一定の間隔を有す る放電がみられた。この成績を他の報告と対比す ると, 白鳥ら（1968）は正常無処置時の放電間隔 は平均 15.6 秒であり, 河野 (1962) は 10.8 秒, 桑島, 西井 (1975) は 13.7 秒で比較的一定であっ たとしている。また，守屋 (1960) は12〜25 秒間 の範囲に大部分が分布すると報告しているが，著 者も同様の結果をえた。選択的近位迷切後では平 均 17.5 秒と放電間隔は延長傾向を示し, また, イヌによっては著明な延長, 短縮を示すものがあ り放電間隔は不安定であった。

全迷切後でも選択的近位迷切後と同様に著明に 延長, 短縮するものがみられ, 放電間隔は不安定 となり，対照と比べ延長傾向を示したが，平均 16.8 秒と選択的近位迷切よりはやや短縮した. 河 野（1962）の報告では，迷切後は放電間隔はやや 
短縮傾向を示すといわれているが，白鳥ら (1968) は全迷切後のイヌ胃に温水を注入する事により, 胃内圧が高字るにつれ放電間隔の延長と逆蠕動の 頻発を認めている.

今回の著者の実験成績をみると, 選択的近位迷 切, 全迷切後に, 同一犬でも放電間隔の延長, お よび短縮といら不安定な結果が得られた。中には 40〜 50 秒と著明な延長を認めるものが多々あり， このため, 平均すると放電間隔の延長傾向となっ て現われたと考えられる。

放電頻度についてみると, 対照では 1 分間の平 均放電頻度は 4.5 回/分であったが, Bass ら

（1961）は 4.4〜5.3 回/分, 横路ら (1976)は 4.5 ５. 5 回／分で規則正しく, 選択的近位迷切後で は一過性に不規則となるが，後には規則的とな

り，全迷切後では周期および波型の著しい不規則 性が術後 2 週間も持続すると述べている．著者の 実験では選択的近位迷切後では対照の 4.5 回/分 から 3.4 回/分に減少するのがみられた。全迷切 後では, 対照と比べ選択的近位迷切後と同様に 3.6 回/分とやはり減少傾向を示した. 全迷切後 は周期は不規則となり，振幅不同を主とした波型 の変化を示すものもみられた。池田（1977）は迷 切後に放電頻度の变化を認めなかったと報告し, 河野 (1962), 清水 (1975) は減少あるいは不変の ものや, やや増加するものもあると報告してい る.

逆蠕動の発生頻度は, 刘照では逆蠕動は全例に 欠如したが, 白鳥ら（1968）は急性実験で無処置 胃では平均 $0.5 \%$ と極めて少ない発生率であった と報告している. 逆に慢性実験での観察で, 田中 ら（1974）は7.4\%の高頻度に発生をみたという. 著者も開腹直後には逆蠕動の発生をみているが， 松岡ら（1963）が開腹時より閉腹時に筋電図が安 定するといっていると同様に, 操作直後の観察を さけ，時間を和いて安定したと思われる時期から 測定したため, 結果的には対照犬で逆蠕動の発生 をみなかったとの結論に達した。 また, 迷切後で は田中ら（1974）は空腹時に打いて選択的近位迷 切後 $18.5 \%$, 選迷切後 $32.9 \%$ 亿逆蠕動の発生を みており, 著者の実験でも, 選択的近位迷切後で は10 頭中 7 頭にみられ, その平均発生頻度は 4. $4 \%$ であった.

全迷切後では 10 頭中 9 頭に逆蠕動の 発生がみ
られ, 平均発生頻度は $6.8 \%$ と前 2 者に比心, 発 生頻度, 頭数ともに増加がみられた。この原因は 白鳥 (1968) のいっているょらに, 迷切を行ら行 なわないにかかわらず, 胃内容量を增し, 胃内压 を高めると, 胃の蠕動運動は次第に光進するが, とくに幽門部で興奮は著明となり，ついには痙戀 様の異常興奮がみられ, 逆蠕動の頻発を来すよう になる。しかし，この所見を迷切前，迷切後につ いて詳細に比較検討すると, 興奮の起こり方に若 干の差異があり，胃内容量をましてほぼ同じ程度 の興奮を起こさせるには，迷切後の方が迷切前よ り多量の胃内容量を必要とすると思われ，これは 迷切によって胃運動機能の減弱ないしは胃壁の緊 張の減弱が起こるためと考兄られた。

伝播速度については, 多くの研究者の報告があ るが，今回は良いデータが出せず見送ることとし た。これは植込及電極を使用しなかったため, 比 較すること自体に意味がなかったためである。お た，白鳥ら（1959）は放電間隔が大となった時に は伝播速度が促進し，放電間隔が小となった時に は伝播速度が遅延する傾向を観察しているが, 著 者は, 対照, 迷切後とも差異を認めなかった。

振幅についてみると, 対照では平均 $0.8 \mathrm{mV} て ゙$ ほぼ一定の大きさの振幅であり, 選択的近位迷切 後では平均 $0.7 \mathrm{mV}$ で対照とほぼ同様であり, ま た, 多少振幅の大きさに相違を認めるものもあっ た. 全迷切後でも平均 $0.8 \mathrm{mV}$ で前 2 者と比べ大 差は認められなかったが, 時折 $4.0 \mathrm{mV}$ 以上の大 きな振幅を有する棘波を認めることがあった。し かし，幽門輪内圧には変化がなかった。

つぎに，幽門輪内压および幽門運動の変化につ いてみると, 対照では, イヌにより大きな差をみ たものもあったが, 幽門輪内圧は平均 $12.2 \mathrm{mmHg}$ で比較的一定の大きさを有する内圧上昇の反復す るのがみられた。選択的近位迷切後では, 平均 $7.0 \mathrm{mmHg}$ と前者に比べ約 $40 \%$ の内圧低下がみ られ，内压上昇もばらつきが著明となり，不安定 となるのがみられた。全迷切後では, 平均内圧は $1.8 \mathrm{mmHg}$ と対照と比較し $85 \%$, 選択的近位迷切 と比べても $74 \%$ と著明な低下を示した。

幽門輪収縮頻度は, 対照では 100\%であり, 放 電に一致して幽門輪が収縮していることを示し た. 選択的近位迷切後では平均収縮頻度は $90.9 \%$ であり, 放電直後にほぼ一致して幽門輪の収縮が 
起こっているととを示した. 全迷切後では $58.6 \%$ となり，必らずしも放電に一致して幽門輪の収縮 が起てるとは限らず，放電が起こっても幽門輪の 収縮が休止するのが多くなることを示している。

平均幽門収縮は, 対照では, 1 分間平均 4.5 回 であった．選択的近位迷切後では平均 3.7 回と多 少減少したが，個々のイヌにより少ないものでは 2.6 回, 多いものでは 5 回と変動を示した。全迷 切後では個々のイヌにより少ないものは 1.3 回, 多いものでも 3.4 回で, 平均 2.3 回と著明な減少 を示した。

幽門輪内圧の測定法として, 最近ひずみ曲線を 用いた実験が多くなってきたが，現時点では，バ ルーン法やひずみ曲線により迷切後の内圧を測定 した報告は少ない.しかし, Nelsen ら（1967）は 筋電図とひずみ曲線を用い, 全迷切あるいは選迷 切後 9 週迄, 幽門輪の収縮と筋電図の出現周期䄮 よびその振幅が不規則となり, 運動量が減少した といっている。おた, Carson \& Litt (1924) はバ ルーンを用いて, イヌの幽門輸内压を測定し, 迷 走神経は幽門に対し運動抑制と促進作用があると いっている. 著者の実験でも, 対照と比較して迷 切後に幽門運動が抑制された結果をえたが，選択 的近位迷切後では幽門の迷走神経が温存されてい るため, 幽門輪内圧の低下は軽度であり, 放電に

\section{結}

10 頭のイヌを用い, 選択的近位迷切, 全迷切後 の胃筋電図，幽門輪内圧を測定し次の結果を兄 た。

1. 対照犬の胃筋電図は規則正しい周期を有す る波型を示し, 逆蠕動の発生はなく, 放電に一致 して大きな幽門輪の内圧上昇をえた。

2. 選択的近位迷切後は放電間隔はやや延長傾 向を示し, 放電頻度は若干減少した。逆蠕動の発 生率は $4.4 \%$ であった。幽門輪内圧は放電にほぼ 一致して起こり, 軽度の圧低下を認めた。また， 幽門収縮数, 幽門輪収縮頻度も軽度減少した.

3. 全迷切後は放電間隔はやはり延長傾向を示 すが，選択的近位迷切よりも軽度であった。放電 頻度も同様に減少したが選択的近位迷切よりも軽 度であった.一方, 逆蠕動の発生率は增加し $6.8 \%$
一致した内圧上昇をえたと思われる。

これに反して全迷切後では，迷走神経の支配を 失ない, その調節性の欠如により，胃壁の緊張が 低下するため内压は著明に低下し，桑島（1977） の報告と同様に高頻度に dysrhythmia が発生し, 筋の疲労現象が起こり, 不応期を起こすので, 放 電に一致した内压上昇がみられなくなると考学ら れる.この不応期後に, 時折大きな内圧の上昇を みることがあったが，これは池田(1976)，Grimson ら (1947), Muren (1957) その他多くの報告で全 迷切後に胃内圧が上昇したといら結果をえている が，不応期が続くことにより，次第に胃内圧の上 昇を来し，この压の蓄積により一時的に大きな幽 門輪内圧の上昇が起こると考えられた。 今回の実 験により, 迷切によって, 胃壁の緊張の減弱, つ まり胃運動機能の減弱, 幽門輪運動機能の減弱を 来し, 胃排出能低下を来すと考えられ, 迷走神経 が胃の排出運動に重要なかかわりがあることが明 らかとなった。

今回の実験で, 選択的近位迷切, 全迷切によっ て幽門の機能低下がみられたが，一連の実験は空 腹時のものであり, 今後食事刺激した場合の機能 の検索が今後の課題として残されていると思われ る.

\section{論}

であった，幽門輪内圧は放電に必らずしも一致し て起こらず，圧は著明に低下し，幽門収縮数，幽 門収縮頻度とも著明に減少した。

以上，選択的近位迷切と全迷切術の何れによっ ても胃運動機能は抑制をらけた。しかし，選択的 近位迷切による運動機能抑制は軽度であったのに 対し, 全迷切後では著明な運動機能抑制を認め た.このことから, 胃運動からみる限り選択的近 位迷切術が全迷切術よりも優れていると結論され た。

稿を終るに臨み，ご指導とご校閲を賜った瀕田孝一教授 並びに 終始直接び指尊ご教示を賜った籏福哲彦講師に深甚 なる謝意を捧げるとともに研究にご支援やご協力を頂いた 教室諸先生に心から感謝の意を表します。 
Bass, P., Code, C.F. \& Lambert, E.H. (1961). Electrical activity of gastroduodenal junction. Am. J. Physiol. 201 : 587-592.

Carslon, A.J. \& Litt, S. (1924). Studies on the visceral nervous system on the reflex control of the pylorus. Arch. Inter. Med. 33: 281-291.

Dragstedt, L.R. \& Owens, F.M. Jr. (1943). Supradiaphragmatic section of vagus nerves in treatment of duodenal ulcer. Proc. Soc. Exp. Biol. 53: 152-154.

Grimson, K.S. et al. (1947). Transthoracic vagotomy, the effects in 57 patients with peptic ulcer and the clinical limitations. J.A.M.A. 134: 925-932.

Griffith, G.A. \& Harkins, H.K. (1957). Partial gastric vagotomy: an experimental study. Gastroenterology 32: 96-102.

Holle, F. (1967). Indikation und Verfahrenswahl bei Ulcus ventriculi. Presented at the 22nd Congress of Societe Internationale de Chirurgie.

池田禎仁 (1976). 胃内圧变動に及ほす外来神経の影響について. 日平滑筋誌 12:87-95.

池田禎仁 (1977)。胃内圧変動に及ほす外来不経切断の影響についての慢性実験. 日平滑筋誌 13:75-84.

河野兵衛 (1962)，筋電図学的立場からみた胃支配神経切断時の胃機能. 東北医誌 65: 548-558.

桑島輝夫 (1977). 各種迷切とイヌ胃運動機能. 日平滑筋誌 $13: 55-67$.

桑島輝夫, 西井 博 (1975). 迷走神経切離術と胃運動機能特に選択的近位迷走神経切離術を中心として. 日平滑 筋誌 $11: 175-188$.

桑島煇夫ら (1975). 植込み電極尊出法による消化管筋電図および電極作製方法と埋没方法. 日平滑筋誌 11:2127.

Muren, A. (1957). Gastric motility after vagotomy in dog. Acta. Chiv. Scand. 112: 98-106.

守屋 明 (1960). 胃の筋電図学的研究. 東北医誌 62:80-82.

松岡健三，北川 晃，南俊之介 (1963). 消化筋の筋電図. 日消外会誌 60:986-990.

Nelsen, T.S. et al. (1967). Alterations in muscular and electrical activity of the stomach following vagotomy. Arch. Surg. 94: 821-835.

大井 実ら (1963)。胃運動機能に関する筋電図学的研究. 外科 $25: 1333-1342$.

大井 実ら (1966)。幽門機能について. 外科 $28: 1326-1332$.

白鳥常男ら (1959)。胃の筋電図学的研究. 東北医誌 60:885-891.

白鳥常男ら (1968). 迷走神経切離術の胃排出障害に関する実験的研究. 日平滑筋誌 4:15-21.

菅原俠治，加藤守彦 (1970). 胃運動に及洔す麻酔の影響. 日平滑筋誌 $6: 213-214$.

榊原幸雄 (1973)。 十二指腸潰瘍に対する近位選迷切併用幽門形成術. Medical Posigraduates 11:59-64.

清水保雄 (1975). 迷走神経切断術後の胃運動異常に関する実験的研究. 日平滑筋誌 11:55-77.

田中直樹ら (1974)。迷走神経の胃運動に及浔す影響に関する実験的研究. 日平滑筋誌 $10: 269-285$.

Weinberg, J.A. (1963). Vagotomy and pyloroplasty in the treatment of duodenal ulcer. Am. J.Surg. 105: 347-351.

横路 洋, 近藤芳夫, 田中大平 (1976). 各種迷切術と胃筋電図. 日平滑筋誌 12:15-24. 